TITLE:

\title{
Distribution of Intertidal Organisms in the Shores of Teluk Aling, Pulau Pinang, Malaysia
}

$\operatorname{AUTHOR}(S):$

AHMAD, OMAR; FANG, TAY PEI; YAHYA, KHAIRUN

\section{CITATION:}

AHMAD, OMAR ... [et al]. Distribution of Intertidal Organisms in the Shores of Teluk Aling, Pulau Pinang, Malaysia. Publications of the Seto Marine Biological Laboratory 2011, 41: 51-61

ISSUE DATE:

2011

URL:

http://hdl.handle.net/2433/159483

RIGHT: 
Publ. Seto Mar. Biol. Lab., 41: 51-61, 2011

\title{
Distribution of Intertidal Organisms in the Shores of Teluk Aling, Pulau Pinang, Malaysia
}

\author{
OMAr AhmaD ${ }^{1}$, TAy Pei FAng ${ }^{1}$ and Khairun YAhya ${ }^{1,2, *}$ \\ ${ }^{1}$ Centre for Marine and Coastal Studies, 11800 Universiti Sains Malaysia, Penang, Malaysia \\ ${ }^{2}$ School of Biological Sciences, 11800 Universiti Sains Malaysia, Penang, Malaysia \\ *Corresponding author : khairun@usm.my
}

\begin{abstract}
Distribution of intertidal organisms were analysed at the sandy and rocky shores of Teluk Aling, Pulau Pinang during the spring tides on August 4 and September 11, 2007.

Four higher taxa were recorded at the sandy shore including Polychaeta, Crustacea, Mollusca and Echinodermata with the highest abundance by phylum Mollusca: $89.4 \%$. The species found to be the most abundant was the button snail, Umbonium vestiarum at the sandy shore during both sampling periods with the highest abundance measured by Importance Species Indices (ISI) at both middle and lower zones with 39.84 and 36.59 , respectively. At the rocky shore, assemblages of Crustacea, Mollusca, Cnidaria as well as Polychaeta were recorded and Crustaceans appeared to be the most abundant with $98 \%$ of total composition. At the rocky shore, Cthamalus sp. showed the highest ISI value among other organisms with 64.67 for the first sampling and 65.41 for the second sampling. The highest diversity, measured by Shannon-Wiener index, $H^{\prime}$ was observed at middle zone of sandy shore for both sampling periods ( 0.951 for first sampling and 1.422 for second sampling) and higher evenness as measured by Pielou Evenness index, $J$ ' with 0.207 and 0.314 respectively. In contrast, the lower zone at the rocky shore appeared to be more diverse as compared to middle zone with $H^{\prime}=1.738$ for the first sampling and 2.309 for the second sampling. Evenness was also higher with 0.673 and 0.769 , respectively. This study also showed that particle size distribution and organic matter along the intertidal gradient influenced the distribution pattern of intertidal organisms at sandy shore. Based on Pearson correlation analysis, the organic content showed a significant correlation with particle size distribution $(p<0.01)$. Lower zone had finer sand and the highest percentage of organic content, therefore could sustain a greater number of species as compared to the sterile upper zone as a result of coarse sand and less organic content. The Isopoda Eurydice sp. was the only species that could withstand the unstable conditions within this zone. The rocky shore showed the most striking zonation pattern compared to sandy shore where there were considerable overlaps of species in their zonation along the intertidal gradient, although organisms may remain quite separate in the sand column.
\end{abstract}

Key words: sandy shore, rocky shore, organic matter, particle size, diversity index

\section{Introduction}

Intertidal ecology plays an important role in marine production, environmental preservation and in developing as well as usage of marine resources. Numerous studies had been conducted on the sandy, rocky as well as mangroves and estuarine ecosystems. (Raffaelli and Hawkins, 1996). Intertidal regions are in close proximity to human activities, thus having considerable extreme value. The intertidal zone is utilized for food and recreation, but anthropogenic actions also had major impacts, with overexploitation, invasive species and climate change being among the problems faced by intertidal communities (Fincham, 1984).

Despite their initial barren and sterile appearance, many sandy beaches support a diverse flora and fauna as indicated in macrofaunal (> 1mm) studies (McLachlan and Jaramillo, 1995). The work of McLachlan (2001) had reported that exposed sandy beaches have highly variable and physically stressful environments. Physical processes such as the action of waves and tides on unconsolidated sediments together with the intertidal swash climate have a major impact on the community structure 
of the macroinfauna. Species have to adapt to life in the sand to ensure that the supply of oxygen and food are sufficient even when they are not protected from wave action when the tide is in. Desiccation is another problem that organisms have to face especially when the tide is low.

In contrast, competition for space in relatively stable substrate such as on rocky beaches is crucial in zonation patterns and community structure (Cornell, 1961; Underwood and Denley, 1984; Wilson, 1991).Thus, organisms on rocky shores are capable to withstand desiccation, whereas those in the sandy shores avoid desiccation (Fincham, 1984).

Sandy shores intertidal organisms are usually burrowers which is a key adaptation for many sandy beach species (McLachlan et al., 1996). The burrowing performance of individual species can have pronounced effects on sediment characteristics by creating local hydrodynamic changes which may also provide larval settlement (Hutchings, 1998) and are often affected by a variety of factors including body size, sediment grain size and water temperature (McLachlan et al., 1996; Nel et al., 1999). They often exhibit regular tidal migration and swash riding behaviors. These behaviors provide them with better feeding opportunities for suspension feeders and scavengers, while taking refuge from vertebrate predators (Brown, 2001; Jaramillo et al., 2001). Rocky shores, on the other hand, provide surface for secure attachment on substratum, not present in mobile or soft sediments. On rocky shores, vertical zonation is part of the striking feature of the intertidal community. The community is distributed into distinct vertical bands of certain species going up the shore. Species ability to overcome desiccation determines their upper limit whereas the lower limit is set by the competition with other species (Raffaelli and Hawkins, 1996). Living at space limited rocky shore, there is a high opportunity for aggressive undercutting, overgrowing and crushing to take place. Mobile organisms such as polychaete, minute coelenterate and gastropod may thrive between the irregular spaces of barnacles and oysters (Chuang, 1973)

Given the importance of sandy beaches for marine ecosystems, baseline data describing the benthic life and ecosystem processes are needed in order to propose sustainable management for these sandy as well as rocky beaches. Furthermore, sandy beaches have high socio-economical values, as it is reflected in their importance for coastal fisheries and tourism. Although beaches are influenced by numerous physical environmental stresses, man has always use beaches and will continue to exploit these ecosystems (McLachlan, 1988). As a consequence, some of the conservation issues associated with intertidal zones have arisen especially due to climate change in recent years where intertidal organisms are subjected to several effects of global climate change, including increased temperatures, sea level rise and increased storminess (Dugan et al., 2004).

Penang National Park was gazetted on April 4, 2003 under the National Park Act 1980. Under this Act, emphasis is given for the preservation and protection of wildlife, plant life and objects of geological, archaeological, historical and ethnological and other scientific interest and through their conservation and utilization to promote education, health, aesthetic values and recreation of the people. Teluk Aling which consists of a sandy shore flanked by rocky shore is under the jurisdiction of the Penang National Park. There is no published work on the distribution of organisms found on the both shores. Given the emphasis given under the National Park Act 1980, it is timely that the distribution of organisms found in the shores of Teluk Aling are described to serve as baseline data for the planning conservation and management of flora and fauna of the Penang National Park.

The present work was initiated with the following objectives, namely to examine the distribution of intertidal species both at sandy and rocky shores of Teluk Aling, Penang National Park, Penang, Malaysia and secondly to determine the diversity and abundance of species within the sampling sites.

\section{Materials and Method}

Sampling sites were located along the sandy and rocky shores of Teluk Aling at the northwest tip of Pulau Pinang (Penang), Malaysia. The Centre for Marine and Coastal Studies (CEMACS) is located at Teluk Aling and facing the North Channel at Latitude N $5^{\circ} 28.00^{\prime}$ Longitude E $100^{\circ} 12.02$ 
geographically. The sandy shore is about $2.5 \mathrm{~km}^{2}$ with a slope of about $10^{\circ}$ while the rocky shore is about $50^{\circ}$.

The beaches were sampled during low tide on August 4 and September 11, 2007. Three transects lines about $30 \mathrm{~m}$ apart were marked perpendicular to the sandy shore, while on the rocky shore, the transect lines were about $2 \mathrm{~m}$ apart. The shores along the transect lines were then divided into three zones, namely upper, middle and lower zones. At each zone along the transect lines, three replicate samples were taken. On the sandy shore, a PVC corer was forced $20 \mathrm{~cm}$ into the sand and the contents were removed with a trowel into a $0.5 \mathrm{~mm}$ sieve mesh. A small scoop of the sample was also taken for particle size and organic content analysis. The sieve was washed with seawater and the animals retained on the sieves were washed into labeled plastic bags before fixing in $8 \%$ formalin solution mixed with Rose Bengal to stain the animals.

Quadrates of various sizes were used to sample organisms on the rocky shore. Densely colonized rocks were sampled by using a $0.01 \mathrm{~m}^{2}(10 \mathrm{~cm} \times 10 \mathrm{~cm})$ quadrat while larger organisms such as the rock oysters, littorinids and limpets were sampled by using a $0.04 \mathrm{~m}^{2}(20 \mathrm{~cm}$ x $20 \mathrm{~cm})$ quadrat as outlined by Underwood and Chapman (2005). Qualitative sampling was also conducted to prevent bias in describing the intertidal fauna of both shores whereby the sandy shore was combed for organisms not caught in the PVC corer and for organisms that are outside the quadrat on the rocky shore.

In the laboratory, the samples were sorted and identified to the lowest taxon possible. Dry sand sieving method was employed to analyse particle size analysis, while organic matter was analysed by direct gravimetric method using a muffle furnace following the method suggested Bale and Kenny (2005) and Raffaelli and Hawkins (1996).

The diversity and evenness of species enumerated was determined by using the Shannon and Wiener diversity index $\left(H^{\prime}\right)$ and the Pielou Evenness index $\left(J^{\prime}\right)$. Abundance of species during both sampling periods was determined by Important Species Index (ISI) (Ludwig and Reynolds, 1988). One-way ANOVA and Pearson correlation were used to estimate the significance of the distribution, abundance, diversity and evenness of organisms at the sandy and rocky shore in relation to particle size and organic content.

\section{Results}

A total of 46 species and 13 species of macrofauna were observed in the sandy and rocky shores, respectively. In the sandy shore, the phyla observed were Polychaeta, Crustacea, and Mollusca, while on the rocky shore; the phyla consisted of Crustacea, Mollusca, Cnidaria and Polychaeta.

A total of 10 families of Polychaeta were found to reside in the sandy shore but only one family (Serpulidae) was found on the rocky shore. Crustaceans found in the sandy shore of Teluk Aling were mostly from the orders Amphipoda, Cumacea, Copepoda, Isopoda and Decapoda. On the rocky shore, the barnacles (Crustacea: Cirripedia) were the dominant inhabitant having interaction with other organisms such as limpets (Siphonaria sp., Cellana sp. and Patelloida sp.), periwinkles as well as Morula sp. which is the predator for the barnacles. Seventeen species of Mollusca were found on the sandy beach; the button snail, Umbonium vestiarum being the most dominant while the rock oysters, Saccostrea cucullata dominates the lower zone of the rocky shore. Echinodermata found in this study consisted mainly of sand dollar. Living in a different niche, sea anemones (Cnidaria) settled in the tidal pools of the rocky shore.

Generally, the highest macrofauna densities were observed at the lower zone of sandy shore in Teluk Aling, comprising of $7.30 \times 10^{5} \pm 1.19 \times 10^{4}$ individuals $\mathrm{m}^{-3}$ during the first sampling and $9.13 \times 10^{5} \pm 1.43 \times 10^{4}$ individuals $\mathrm{m}^{-3}$ in the second sampling. The macrofauna density in the middle zone was $3.35 \times 10^{5} \pm 5.35 \times 10^{3}$ individuals $\mathrm{m}^{-3}$ in the first sampling and $4.47 \times 10^{5} \pm 7.41 \times 10^{3}$ individuals $\mathrm{m}^{-3}$ in the second sampling. Coarse grained sand of the upper zone was impoverished where only the sand lice, Eurydice sp. (Isopoda) occupied the habitat with a density of $71 \pm 140$ 
individuals $\mathrm{m}^{-3}$ for both sampling periods. Ten out of 46 macrofauna species found in the sandy shore were ecologically important species according to Importance Species Index (ISI). They were Umbonium vestiarum, Eurydice sp., Syllis sp., Bodotria sp. 2, Macoma sp., Homolopoma rubrum, Bodotria sp.1, Veremolpha sp., Notomastus sp. and Goniadopsis maskallensis. The list of organisms found in the sandy shore is summarized in Table 1. Shannon-Weiner index, $H^{\prime}$ ' and Evenness, $J$ ' were higher during the second sampling due to a decrease in the Importance Species Index of Umbonium vestiarum from 39.84 in the first sampling to 36.59 in the second sampling.

The rocky shore provides a large number of integrating habitats, with associated fauna different degrees of complexity. Table 2 gives a list of the common animals found on the intertidal rocks at Teluk Aling. During the first sampling, the upper zone consisted of $2.72 \times 10^{5} \pm 1.0 \times 10^{4}$ individuals $\mathrm{m}^{-2}$ compared to the middle and lower zone which have densities of $2.58 \times 10^{5} \pm 1.14 \times 10^{4}$ individuals $\mathrm{m}^{-2}$ and $3.13 \times 10^{4} \pm 1.07 \times 10^{3}$ individuals $\mathrm{m}^{-2}$, respectively. The middle zone, on the other hand, showed the highest densities during the second sampling, i.e. with $2.49 \times 10^{5} \pm 5.35 \times 10^{3}$ individuals $\mathrm{m}^{-2}$ while the upper and lower zones with densities of $2.35 \times 10^{5} \pm 9.65 \times 10^{3}$ individuals $\mathrm{m}^{-2}$ and $1.26 \mathrm{x}$ $10^{4} \pm 3.97 \times 10^{2}$ individuals $\mathrm{m}^{-2}$, respectively. The density was high at the upper zone due to Chthamalus sp. which was found to be dominant. According to the ISI calculated for rocky shore, there is little difference between the ten most abundant species for the two sampling periods. The most important species were Chthamalus sp., Balanus sp., Siphonaria sp., Saccostrea cucullata, Patelloida sp., Cellana sp., Morula sp., Nodilittorina trochoides, Tetraclita sp. and Spirobis sp. A higher diversity, $H^{\prime}$ and Evenness, $J$ ' was observed at the lower zone on both sampling periods on the rocky shore. The lower zone is the least exposed in terms of time, thus the physical stress on the organisms living at this zone is minimal.

The sequence of dominant organisms from the upper supralittoral to the lower sublittoral resulted in the following zonation as illustrated in Fig. 2.

(i) Upper barnacle or Chthamalus zone: Chthamalus sp. was usually abundant in the upper region to mid littoral, little substratum was available to other organisms. Co-existing in this zone were Balanus sp., Patellioda sp. and Nodilittorina trochoides.

(ii) Middle barnacle or Balanus sp. zone: Balanus sp. was dominant from this zone and extending

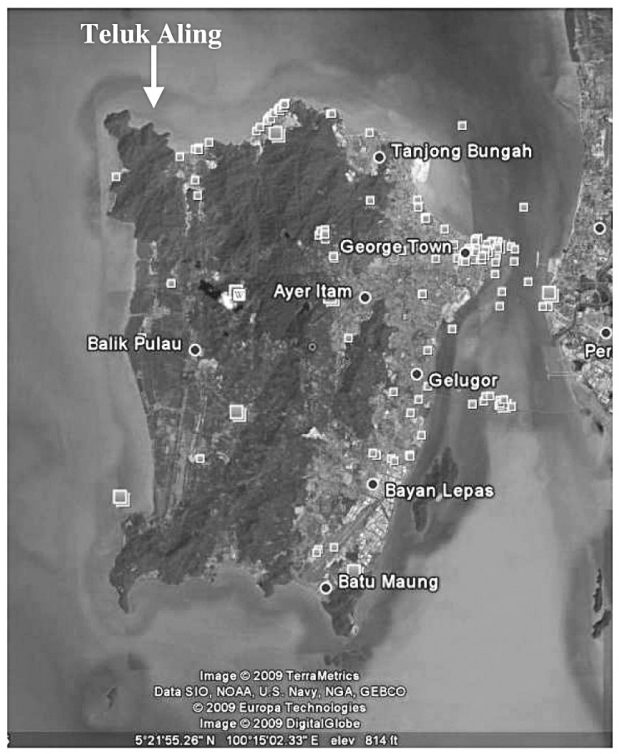

Fig. 1. Map of Pulau Pinang, Malaysia showing the sampling location. 
Table 1. Abundance of organisms $\left(\mathrm{m}^{3}\right)($ mean $\pm \mathrm{SD})$ present on the sandy shore of Teluk Aling.

\begin{tabular}{|c|c|c|c|c|c|c|c|c|}
\hline Species & $\begin{array}{l}\text { Upper } \\
\text { zone }\end{array}$ & $\begin{array}{l}\text { Middle } \\
\text { zone }\end{array}$ & $\begin{array}{l}\text { Lower } \\
\text { zone }\end{array}$ & $\begin{array}{l}\text { Importance } \\
\text { Species } \\
\text { Index, ISI }\end{array}$ & \multicolumn{3}{|c|}{$\begin{array}{l}\text { Second sampling (September } 11 \\
\text { 2007) }\end{array}$} & $\begin{array}{l}\text { Importance } \\
\text { Species } \\
\text { Index, ISI }\end{array}$ \\
\hline \multicolumn{9}{|l|}{ POLYCHAETA } \\
\hline $\begin{array}{l}\text { Goniadopsis } \\
\text { maskallensis }\end{array}$ & & $177 \pm 231$ & $106 \pm 225$ & 0.13 & & $35 \pm 106$ & $283 \pm 249$ & 0.08 \\
\hline Syllis sp. & & $460 \pm 453$ & $4633 \pm 9987$ & 1.54 & & $6860 \pm 1427$ & $1344 \pm 1145$ & 3.17 \\
\hline \multicolumn{9}{|l|}{ Prionospio sexoculata } \\
\hline & & $141 \pm 231$ & & 0.01 & & $35 \pm 106$ & $1308 \pm 1012$ & 0.30 \\
\hline \multicolumn{9}{|l|}{ Prionospio pinnata } \\
\hline & & & $71 \pm 212$ & 0.01 & & & $424 \pm 318$ & 0.05 \\
\hline \multicolumn{9}{|l|}{ Prionospio } \\
\hline cirrobranchiata & & $35 \pm 106$ & & 0.01 & & $177 \pm 231$ & $212 \pm 421$ & 0.11 \\
\hline Notomastus sp. & & $106 \pm 225$ & $389 \pm 414$ & 0.17 & & $71 \pm 212$ & $177 \pm 231$ & 0.07 \\
\hline Scoloplos sp. & & $71 \pm 140$ & $35 \pm 106$ & 0.05 & & $177 \pm 281$ & $177 \pm 323$ & 0.11 \\
\hline Cirratulus sp. & & $106 \pm 225$ & & 0.03 & & & $71 \pm 140$ & 0.01 \\
\hline Sigalion sp. & & $71 \pm 212$ & & 0.02 & & & $71 \pm 140$ & 0.01 \\
\hline Pontogenia sp & & $35 \pm 106$ & & 0.01 & & & & \\
\hline Maldanella sp. & & & & & & & $141 \pm 168$ & 0.02 \\
\hline Harmothoe sp. & & & & & & & $71 \pm 140$ & 0.01 \\
\hline Micronereides sp. & & $35 \pm 106$ & & 0.01 & & & $35 \pm 106$ & 0.01 \\
\hline Spionidae & & $35 \pm 106$ & & 0.01 & & & $35 \pm 106$ & 0.01 \\
\hline Hesionidae & & & & & & $106 \pm 225$ & & 0.02 \\
\hline \multicolumn{9}{|l|}{ CRUSTACEA } \\
\hline \multicolumn{9}{|l|}{ CUMACEA } \\
\hline Bodotria sp. 1 & & $318 \pm 574$ & $177 \pm 323$ & 0.24 & & $743 \pm 1253$ & $1344 \pm 1533$ & 0.61 \\
\hline Bodotria sp.2 & & $1379 \pm 2312$ & $248 \pm 310$ & 0.89 & & $955 \pm 1283$ & $1202 \pm 1004$ & 0.66 \\
\hline \multicolumn{9}{|l|}{ AMPHIPODA } \\
\hline Synchelidium sp. & & & & & & $35 \pm 106$ & $1096 \pm 982$ & 0.25 \\
\hline Platyischnopus sp. & & & & & & $35 \pm 106$ & $71 \pm 140$ & 0.03 \\
\hline Perioculodes pallidus & & & $35 \pm 106$ & 0.01 & & & & \\
\hline Gammaropsis sp. & & & & & & & $106 \pm 225$ & 0.05 \\
\hline ISOPODA & & & & & & & & 0.01 \\
\hline Paragnathia sp. & & & & & & $35 \pm 106$ & & \\
\hline $\begin{array}{l}\text { Eurydice sp. } \\
\text { COPEPODA }\end{array}$ & $71 \pm 140$ & & & 11.10 & $71 \pm 140$ & & $35 \pm 106$ & 22.24 \\
\hline Harpacticus sp. & & & $141 \pm 231$ & 0.02 & & $884 \pm 1430$ & $177 \pm 530$ & 0.41 \\
\hline
\end{tabular}


Table 1. Continued

\begin{tabular}{|c|c|c|c|c|c|c|c|c|}
\hline Species & $\begin{array}{l}\text { Upper } \\
\text { zone }\end{array}$ & $\begin{array}{c}\text { Middle } \\
\text { zone }\end{array}$ & $\begin{array}{c}\text { Lower } \\
\text { zone }\end{array}$ & $\begin{array}{l}\text { Importance } \\
\text { Species } \\
\text { Index, ISI }\end{array}$ & $\begin{array}{l}\text { Seconc } \\
\text { Upper } \\
\text { zone }\end{array}$ & $\begin{array}{c}\text { sampling ( } \\
2007) \\
\text { Middle } \\
\text { zone }\end{array}$ & $\begin{array}{c}\text { ptember } 11 \\
\text { Lower } \\
\text { zone }\end{array}$ & $\begin{array}{l}\text { Importan } \\
\text { Species } \\
\text { Index, IS }\end{array}$ \\
\hline Corycaeus sp. & & & & & & $35 \pm 106$ & & 0.01 \\
\hline \multicolumn{9}{|l|}{ DECAPOPDA } \\
\hline Matuta lunaris & & & $35 \pm 106$ & 0.01 & & & & \\
\hline Diogenes sp. & & & $248 \pm 444$ & 0.03 & & & & \\
\hline \multicolumn{9}{|l|}{ MOLLUSCA } \\
\hline \multicolumn{9}{|l|}{ GASTROPODA } \\
\hline \multirow[t]{2}{*}{ Umbonium vestiarum } & & $32782 \pm$ & $73909 \pm$ & 39.84 & & $40059 \pm$ & $90317 \pm$ & 36.59 \\
\hline & & 17151 & 34078 & & & 28742 & 39960 & \\
\hline \multicolumn{9}{|l|}{ Homalopoma rubrum } \\
\hline & & $283 \pm 404$ & $248 \pm 444$ & 0.24 & & $1733 \pm 859$ & $707 \pm 569$ & 0.88 \\
\hline Nassarius suturalis & & $177 \pm 231$ & $71 \pm 140$ & 0.13 & & $35 \pm 106$ & $71 \pm 140$ & 0.03 \\
\hline \multicolumn{9}{|l|}{ Nassarius } \\
\hline jacksonianus & & & & & & $106 \pm 318$ & $495 \pm 619$ & 0.15 \\
\hline Natica tigrina & & $71 \pm 140$ & & 0.02 & & & $141 \pm 231$ & 0.02 \\
\hline Natica maculosa & & & $35 \pm 106$ & 0.01 & & & $141 \pm 168$ & 0.02 \\
\hline Polinices mammatus & & & & & & & $71 \pm 212$ & 0.01 \\
\hline Acteon $\mathrm{sp}$ & & $35 \pm 106$ & $106 \pm 159$ & 0.05 & & $141 \pm 168$ & $71 \pm 140$ & 0.07 \\
\hline Turris sp. & & & & & & & $35 \pm 106$ & 0.01 \\
\hline Cerithium sp. & & & $141 \pm 231$ & 0.02 & & $71 \pm 140$ & $35 \pm 106$ & 0.04 \\
\hline Thais carinifera & & & & & & & $35 \pm 106$ & 0.01 \\
\hline Crepidula sp. & & & & & & & $35 \pm 106$ & 0.01 \\
\hline Mitridae & & $71 \pm 212$ & $177 \pm 323$ & 0.09 & & & & \\
\hline Marginellidae & & $35 \pm 106$ & & 0.01 & & & $35 \pm 106$ & 0.01 \\
\hline \multicolumn{9}{|l|}{ BIVALVIA } \\
\hline Macoma sp. & & $460 \pm 731$ & $106 \pm 159$ & 0.30 & & $389 \pm 472$ & $35 \pm 106$ & 0.17 \\
\hline Veremolpha sp. & & $248 \pm 265$ & $71 \pm 140$ & 0.17 & & $71 \pm 212$ & $177 \pm 530$ & 0.07 \\
\hline \multicolumn{9}{|l|}{ ECHINODERMATA } \\
\hline Clypeaster bisforatus & & & $71 \pm 140$ & 0.01 & & & $248 \pm 348$ & 0.03 \\
\hline \multicolumn{9}{|l|}{ SIPUNCULA } \\
\hline Sipunculus sp. & & $35 \pm 106$ & $106 \pm 225$ & 0.05 & & $248 \pm 444$ & $460 \pm 506$ & 0.20 \\
\hline \multicolumn{9}{|l|}{ Shannon-Weiner } \\
\hline index, $H^{\prime}$ & & 0.951 & 0.647 & & & 1.422 & 0.962 & \\
\hline Evenness index, $J$ & & 0.207 & 0.145 & & & 0.314 & 0.185 & \\
\hline
\end{tabular}


Table. 2. Abundance of oganisms $\left(\mathrm{m}^{2}\right)($ mean $\pm \mathrm{SD})$ present on the rocky shore of Teluk Aling.

\begin{tabular}{|c|c|c|c|c|c|c|c|c|}
\hline \multirow{2}{*}{ Species } & \multicolumn{3}{|c|}{ First Sampling (Aug 4 2007) } & \multirow{2}{*}{$\begin{array}{l}\text { Important } \\
\text { Species } \\
\text { Index, ISI }\end{array}$} & \multicolumn{3}{|c|}{ Second sampling (September 11 2007) } & \multirow{2}{*}{$\begin{array}{l}\text { Important } \\
\text { Species } \\
\text { Index, ISI }\end{array}$} \\
\hline & $\begin{array}{l}\text { Upper } \\
\text { zone }\end{array}$ & $\begin{array}{c}\text { Middle } \\
\text { zone }\end{array}$ & Lower zone & & $\begin{array}{c}\text { Upper } \\
\text { zone }\end{array}$ & $\begin{array}{c}\text { Middle } \\
\text { zone }\end{array}$ & Lower zone & \\
\hline \multicolumn{9}{|l|}{ CRUSTACEA } \\
\hline Chthamalus sp. & $\begin{array}{c}29456 \pm \\
7941\end{array}$ & $\begin{array}{c}25067 \pm \\
20368\end{array}$ & $622 \pm 650$ & 64.67 & $\begin{array}{c}25578 \pm \\
9750\end{array}$ & $24200 \pm 7871$ & $311 \pm 289$ & 65.41 \\
\hline Balanus sp. & $333 \pm 568$ & $2822 \pm 832$ & $2533 \pm 1597$ & 23.99 & $122 \pm 179$ & $2611 \pm 1140$ & $811 \pm 655$ & 17.01 \\
\hline Tetraclita $\mathrm{sp}$. & & $89 \pm 117$ & $67 \pm 87$ & 0.11 & & $144 \pm 113$ & $111 \pm 93$ & 0.21 \\
\hline Euraphia sp. & & $100 \pm 87$ & & 0.04 & & $222 \pm 148$ & & 0.09 \\
\hline \multicolumn{9}{|l|}{ MOLLUSCA } \\
\hline $\begin{array}{l}\text { Saccostrea cucullata } \\
\text { GASTROPODA }\end{array}$ & $67 \pm 115$ & $208 \pm 113$ & $442 \pm 563$ & 3.88 & $33 \pm 58$ & $317 \pm 88$ & $350 \pm 563$ & 6.38 \\
\hline Nodilittorina trochoides & $175 \pm 303$ & $58 \pm 101$ & & 0.17 & $567 \pm 551$ & & & 0.24 \\
\hline Littoraria $\mathrm{sp.}$ & $42 \pm 72$ & & & 0.01 & $108 \pm 95$ & & & 0.24 \\
\hline Morula sp. & $17 \pm 29$ & $325 \pm 563$ & & 0.25 & $25 \pm 25$ & & $8 \pm 14$ & 0.12 \\
\hline Siphonaria sp. & $558 \pm 375$ & $1033 \pm 621$ & $317 \pm 465$ & 4.31 & $75 \pm 43$ & $850 \pm 413$ & $208 \pm 14$ & 4.63 \\
\hline Patelloia sp. & $117 \pm 38$ & $158 \pm 101$ & $133 \pm 189$ & 1.38 & $8 \pm 14$ & $167 \pm 95$ & $192 \pm 250$ & 3.47 \\
\hline Cellana sp. & $117 \pm 101$ & $42 \pm 38$ & $75 \pm 66$ & 0.78 & $8 \pm 14$ & $75 \pm 25$ & $58 \pm 101$ & 1.08 \\
\hline $\begin{array}{l}\text { CNIDARIA } \\
\text { ACTINARIA }\end{array}$ & & & & & & & & \\
\hline $\begin{array}{l}\text { Actinaria } \text { sp } \\
\text { POLYCHAETA }\end{array}$ & & & & & & $67 \pm 76$ & & 0.03 \\
\hline Spirobis sp. & $8 \pm 14$ & $17 \pm 29$ & & 0.02 & & $50 \pm 87$ & $17 \pm 29$ & 0.23 \\
\hline $\begin{array}{l}\text { Shannon-Weiner } \\
\text { index, } H^{\prime}\end{array}$ & 0.412 & 0.947 & 1.738 & & 0.337 & 0.931 & 2.309 & \\
\hline Evenness index, $J$ & 0.119 & 0.274 & 0.673 & & 0.101 & 0.280 & 0.769 & \\
\hline
\end{tabular}

down to the lower zone. Co-existing in this zone were Siphonaria sp., Morula sp., Tetraclita sp. and Actinaria sp. settled in the crevices of the rocks and closed up when the tide recede. Another species of barnacle, Euraphia sp. can seldom be found occurring in this region.

(iii) Oyster zone: In this zone, the rock oyster, Saccostrea cucullata were found from the middle zone to the lower zone. Individual oysters abutted each other closely and there was no space for the attachment of other organisms. Seaweed (mostly Amphiroa sp.) and oysters were intermingled in this region.

One-way ANOVA $(\mathrm{p}<0.05)$ tests showed that the abundance of organisms found at the different zones on sandy shore were significantly different. On the other hand, one-way ANOVA indicated that the abundance of organisms was not significantly different $(\mathrm{p}<0.05)$ between the zones on the rocky shore. A Pearson correlation of organic matter versus particle size showed that organic content decreased significantly $\mathrm{p}<0.05)$ as the mean particle size increased. Distribution of organisms according to phylum was significantly $(\mathrm{p}<0.01)$ correlated to organic content, for Polychaete $(\mathrm{r}=$ 0.926), Mollusca $(r=0.925)$, and Crustacea $(r=0.807)$, respectively.

\section{Discussion}

The number of species in Teluk Aling increases from the supralittoral zone to the littoral zone, a characteristic of the sandy shore habitat (McLachlan, 2001; Dexter, 1979; Dexter, 1990). With increasing sediment stability, species richness and abundance were markedly higher at the lower zone than that recorded in the middle and upper zone. However, Shannon and Weiner diversity index, $H^{\prime}$ for the lower zones was on average lower than for middle zone as seen in Table 1 . This is due to the fact that diversity in one habitat is the results from various combinations of species richness and evenness (Ludwig and Reynolds, 1988). The dominance of Umbonium vestiarum in the lower zone also resulted in low evenness index, $J^{\prime}$. A study of 22 tropical American intertidal shores showed that $H^{\prime}$ 'values ranged from 0.5 to 3.9 and $J$ ' ranged from 0.17 to 0.94 , while in 16 warm temperate Australian beaches ranged from 0.5 to 2.7 and $J$ ' ranged from 0.22 to 0.67 (Dexter, 1976, 1979, 1985, 


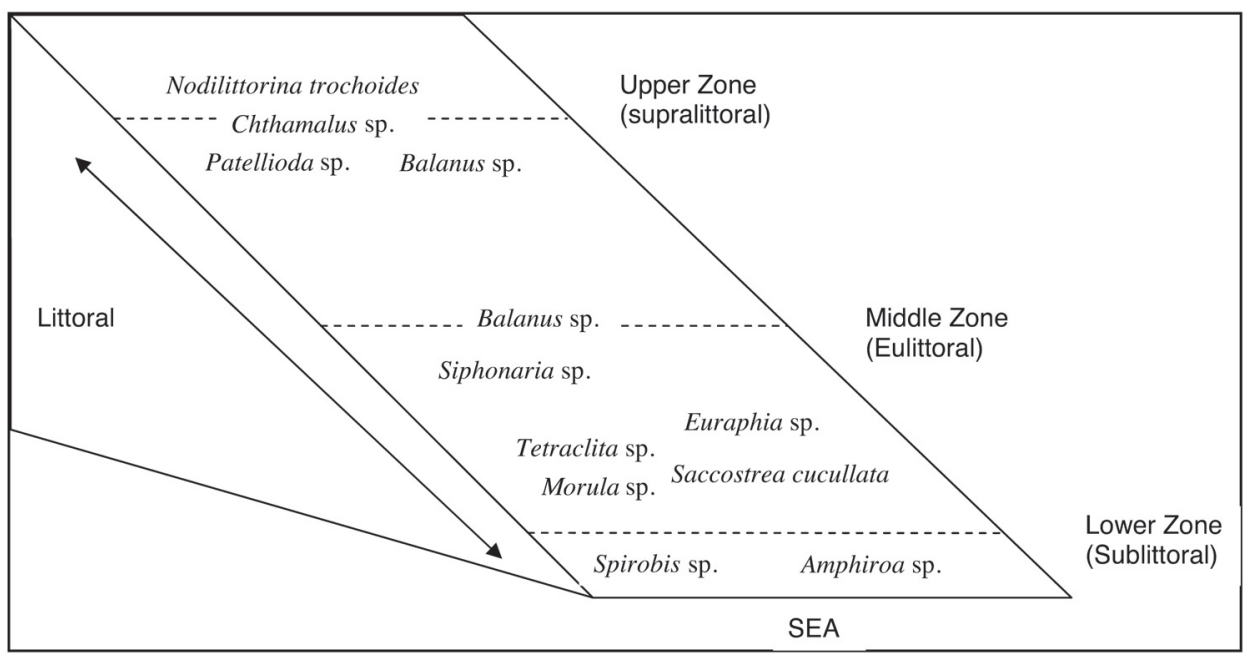

Fig. 2. Schematic diagram of the distribution of organisms on the rocky shore at Teluk Aling, Pulau Pinang, Malaysia.

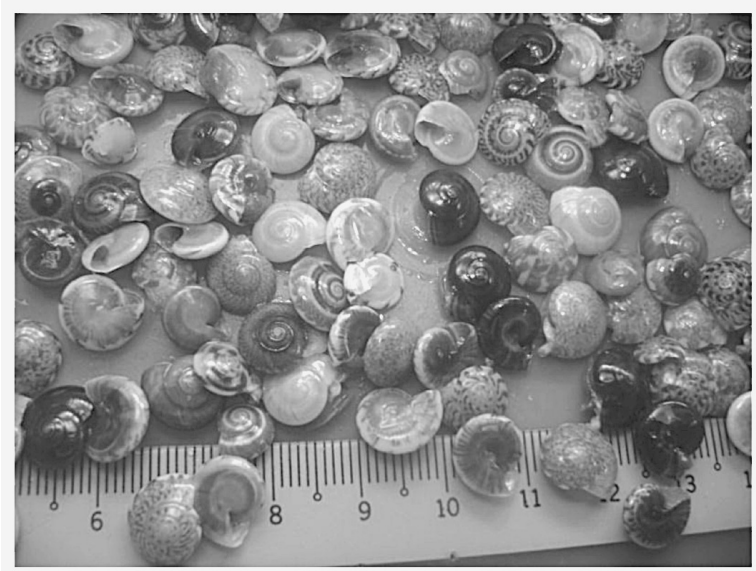

Fig. 3. Umbonium vestiarum, the dominant species on the sandy shore.

1988). The diversity in Teluk Aling intertidal shore is considered low as $H^{\prime}$ ranged from 0 to 1.42 while evenness, $J$ ' ranged from 0 to 0.31 when compared to the tropical American beaches or warm temperate Australian beaches. However, Teluk Aling is better off compared to the intertidal beaches of Portugal with a striking characteristic of having coarse sediment associated with intertidal density of less than 1 organism m² (Dexter, 1989).

Pearson correlation $(\mathrm{p}<0.01)$ showed that organisms density increased significantly as mean particle size decreases. Such correlation had been observed for other sandy shore such as Sinai Red Sea and Mediterranean sandy beaches (Dexter, 1986; McLachlan, 1983). Moving up to the intertidal zone in Teluk Aling, the sand become coarser compared to middle and lower zone. Seawater in the retreating wave will gradually percolate down through the sediment and little material will be carried back to the shore in the backwash (Raffaelli and Hawkins, 1996). Moving down to the vertical gradient of the sandy shore, the smaller particles at the lower zone retain some water at low tide 
Table 3. Cumulative particle size distribution and percentage organic matter in the sandy shore of Teluk Aling, Pulau Pinang.

\begin{tabular}{cccc}
\hline Particle & Upper & Middle & Lower \\
Size & zone & zone & zone \\
\hline$\mu \mathrm{m})$ & $(\%)$ & $(\%)$ & $(\%)$ \\
\hline$<63$ & 0.00 & 0.11 & 0.16 \\
$125-63$ & 0.54 & 2.19 & 15.83 \\
$250-125$ & 32.99 & 54.28 & 64.38 \\
$425-250$ & 25.04 & 25.61 & 15.13 \\
$600-425$ & 13.14 & 8.19 & 3.05 \\
$1000-600$ & 19.02 & 5.27 & 1.20 \\
$>1000$ & 9.21 & 4.41 & 0.20 \\
$\begin{array}{l}\text { Organic } \\
\text { matter } \\
\text { content }\end{array}$ & $0.74 \pm 0.21$ & $2.04 \pm 0.40$ & $3.73 \pm 1.76$ \\
\hline
\end{tabular}

through capillary action. The organism assemblage at this zone will have low risk of physical damage as organisms are relatively large compared to the particle size as shown by studies performed in Argentina Patagonian gulfs (Jaramillo et al. 2001). A negative correlation was observed in Teluk Aling between mean particle size and organic content. Organic content is due to the decomposition of complex organic matter by microbial activity and often binds sediment together in a matrix body (Raffaelli and Hawkins, 1996). The smaller particles at lower zone have a much larger surface area relative to its volume than a larger particle at upper zone; therefore microorganisms are more able to attach to the surface of sand grains. The effect of microbial component in the sandy shore stabilizes the sediment by secreting an amount of mucopolysaccharides that glue the sediment particles together (Raffaelli and Hawkins, 1996), thus giving the characteristic of little muddy at the lower zone in Teluk Aling. Water drains freely during the ebb tide in the coarser sand particles at the middle and lower zones due to the large gaps between the sand particles ant the capillary forces which hold onto the water are weak. This situation does not allow the attachment of microorganisms onto the large surface area therefore resulting in decreased organic content upwardly to the upper zone.

Interactions between exposure and particle size, and their consequences for sediment chemistry have a fundamental effect on the distribution and abundance of organisms. Organisms utilize the swash to move around the shore and for feeding, typically suspension feeders such as amphipods (Raffaelli and Hawkins, 1996). Indeed, gastropods and decapods such as moon crab exploit exposed conditions, surfing up and down the shore with the ebb and flood of the tides to feed. The lower zone was populated by the greatest number of species, dominated by an association of deposit and filter feeders. Little overlap between assemblages of deposit and filter feeders was found in the middle and lower zones at Teluk Aling. The upper part of the sandy beach at Teluk Aling was dominated by the cirolanid isopod Eurydice sp. Cirolanid isopods are characteristic species of sandy shores and had been identified to survive at higher tidal levels with unstable conditions (Dexter,1985).

At the other end of the particle size gradient, the rocky shore, interactions between wave exposure and particle size is possibly the main process in shaping up the biological characteristics of the rocky 
shore (Raffaelli and Hawkins, 1996). The organisms at rocky shore are sufficiently small, in relation to particle size in order to maintain themselves on the rock surface. In contrast to sandy shore where organisms were mostly mobile, the rocky shore was characterized by sedentary or slow moving organisms. Due to the sessile form of the organisms, there are often scenarios of species overgrowing, aggressive undercutting and crushing of individuals. The overcrowding effects were obvious in the shape of the valves of the rock oysters, Saccostrea cucullata at rocky shore which are mostly irregular.

Species found at the upper zone of rocky shore of Teluk Aling such as Chthamalus sp, Cellana sp., Nodilittorina sp. and Littoraria sp. possess certain morphological features to cope with the hostile conditions prevalent at the upper zone. For example, species of high shore limpets such as Cellana sp. tend to have a more domed-shape shells compared to other limpets (Raffaelli and Hawkins, 1996). Other gastropods such as Nodilittorina sp. and Littoraria sp. reduce contact with the hot substratum by producing mucus and is often seen that they withdraw inside their shells when the tide is out. Balanus sp. that is found dominant at the middle zone tends to retreat inside a closed shell when they are exposed to desiccation. The distribution of species at rocky shore of Teluk Aling is similar to that reported by Purchon and Enoch (1954) in Singapore.

Although universal features of tropical rocky shore zonation are recognizable in Teluk Aling zonation pattern of individual species within the major zones is not clear in this study due to the patchy distribution of the species as indicated by the standard deviation as seen in Table 2. Patchiness is a basic feature of rocky intertidal zone, generated by physical or biological activity (Nybakken, 1982). Experiments on patchiness have shown that on some shores, there are keystone predators or grazers that efficiently maintain community composition and structure. Limpets found in Teluk Aling may be one of the important grazers to cause the characteristic patch of algae and lichen in association with each individual limpet. The predation of barnacles by Morula sp. and Thais echinata has been observed to cause considerable damage on the rocky shore. Coexistence of several species enhanced the diversity of the community; yet, some species of predators are needed to act at different levels in the competitive hierarchy for the sake of community maintenance. These conditions interact to set the distribution limit of many mid and lower zone species (Raffaelli and Hawkins, 1996).

In conclusion, the composition of intertidal organisms in the sandy shore of Teluk Aling increases downward towards the lower zone but the diversity of organisms is higher at the middle zone. This is reflected by the diversity and evenness indices of species distribution in the sandy shore as seen in Table 1. Umbonium vestiarum appears to be the most dominant species in the sandy shore. The universal zonation of rocky shore is detected in Teluk Aling although one-way ANOVA test indicated that the abundance of organisms was not significantly different between the zones on the rocky beach.

\section{Acknowledgements}

Publication of this paper is financially supported in part by Natural Geography In Shore Areas (NaGISA) and Ministry of the Environment Japan (The Environment Research and Technology Development Fund S-9).

\section{References}

Bale, A. J. and Kenny, A. J. 2005. Sediment Analysis and Seabed Characterization. In, A. Eleftheriou and A. McIntyre (Eds.), Methods for the Study of Marine Benthos, Blackwell Science, Third Edition, Oxford, pp.4386.

Brown, A. C. 2001. Surfing in the sandy-beach Whelk, Bullia digitalis (Dillwyn). African Zoology, 36: 121-127.

Chuang, S. H. (Ed.) 1973. Animal Life and Nature in Singapore. Singapore University Press, Singapore. pp. 150201.

Connell, J. H. 1961. The influence of interspecific competition and other factors on the distribution of the barnacle, Chthamalus stellatus. Ecology, 42: 133-146.

Dexter, D. M. 1976. The sandy beach fauna of Mexico. Southwestern Nature, 20: 479-485.

Dexter, D. M. 1979. Community structure and seasonal variation in intertidal Panamian sandy beaches. Estuarine, 
Coastal and Shelf Science, 9: 534-558.

Dexter, D. M. 1985. Distribution and life histories of abundant crustaceans of four sandy beaches of South-eastern New South Wales. Australian Journal of Marine and Freshwater Research, 36: 281-289.

Dexter, D. M. 1986. Sandy beach fauna of Mediterranean and Red Sea coastlines of Israel and the Sinai Peninsula. Israel Journal of Zoology, 34: 125-138.

Dexter, D. M. 1988. The sandy beach fauna of Portugal. Nova Serie, 1 (8): 101-110.

Dexter, D. M. 1989. The sandy beach fauna of Egypt. Estuarine, Coastal and Shelf Science, 29: 261-271.

Dexter, D. M. 1990. The effect of exposure and seasonality on sandy beach community structure in Portugal. Cience. Biological and Ecological System (Portugal), 10 (1-2): 31-50.

Dugan, J. E., Jaramillo, E., Hubbard, D.M., Conteras, H and Duarte, M. 2004. Competitive interactions in macroinfaunal animals of exposed sandy beaches. Oecologia, 139: 630-640.

Fincham, A. A. 1984. Basic Marine Biology. British Museum (Natural History), Cambridge University Press, London, $157 \mathrm{pp}$.

Hutchings, P. 1998. Biodiversity and functioning of polychaetes in benthic sediments. Biodiversity and Conservation, 7: 1133-1145.

Jaramillo, E., Conteras, H., Duarte, M and Quijon, P. 2001. Relationships between community structure of the intertidal macroinfauna and sandy beach characteristics along the Chilean Coast. Marine Ecology, 22: 323342.

Ludwig, J. A. and Reynolds, J. F. 1988. Statistical Ecology. A Primer on Methods and Computing, Wiley Interscience Publication, New York, 337 pp.

McLachlan, A. 1983. Sandy beach ecology. A review. In, A. McLachlan and T. Erasmus (Eds.). Sandy beaches as Ecosystems. Dr. W. Junk Publ., The Hague, pp. 321-380.

McLachlan, A. 1988. Behavioural adaptations of sandy beach organisms: an ecological perspective. In, G. Chelazzi and M. Vannini (Eds.).Behavioural adaptation to intertidal life. Plennum Press, New York, pp. 449475.

McLachlan, A. 2001. Coastal beach ecosystems. In, Encyclopedia of Biodiversity. Vol. 1, Academic Press, London, pp. 741-751.

McLachlan, A. and Jaramillo, E. 1995. Zonation on sandy beaches. Oceanography and Marine Biology Annual Reviews, 33: 305-335.

McLachlan, A., Dugan, E., Defeo, O., Ansell, A., Hubbard, D, Jaramillo, E. and Penchahaszadeh, P. 1996. Beach and fisheries. Oceanography and Marine Biology Annual Reviews, 3: 163-232.

Nel, R., McLachlan, A. and Winter, D. 1999. The effect of sand particle size on the burrowing ability of the beach mysid Gastrosaccus psammodytes Tattersall. Estuarine, Coastal and Shelf Science, 48: 599-604.

Nybakken, J. W. 1982. Marine Biology. An Ecological Approach. 4th Ed. Addison Wesley Longman Inc., pp. 219-301.

Purchon, R. D. and Enoch, I. 1954. Zonation of the marine fauna and flora on a rocky shore near Singapore. The Raffles Bulletin of Zoology, 25: 47-65.

Raffaelli, D. and Hawkins, S. 1996. Intertidal Ecology. Chapman and Hall, London, 356 pp.

Underwood, A. J. and Chapman, M. G. 2005. In, A. Eleftheriou and A. McIntyre (Eds.), Methods for the Study of Marine Benthos, Blackwell Science, Third Edition, Oxford, pp. 1-42.

Underwood, A. J. and Denley, E. J. 1984. Paradigms, explanations and generalizations i9n models for the structure of intertidal communities on rocky shores. In, D. Simberloff (Ed.). Ecological communities: conceptual issues and evidence. Princeton, New Jersey, pp. 151-180.

Wilson, H. W. 1991. Competition and predation in marine soft sediment communities. Annual Reviews of Ecological Systems, 21: 221-241. 